\title{
Insect Pests of Tomato and Their Weather Relations under Open and Cover Cultivation
}

\author{
Nagamandla Ramya Sri*, Shantanu Jha and Nagulapally Sneha Latha
}

Bidhan Chandra krishi viswavidhyalaya, Faculty of agriculture, Mohanpur, Nadia,

West Bengal, 741252, India

*Corresponding author

\section{A B S T R A C T}

Tomato is most popular and widely grown vegetable in the world and suffering from both biotic and abiotic stresses. Aphis gossypii, Bemisia tabaci, Thrips tabaci, Liriomyza trifolii,

Keywords

Tomato pests,

Weather relations,

Open field, Cover cultivation.

\section{Article Info}

Accepted:

04 July 2017

Available Online:

10 September 2017 Spodoptera liura and Helicoverpa armigera are the major important insects and causing severe losses under favorable weather condition. The proposed research study was conducted during 2016-17 at Central Research Farm, BCKV. On Tomato (Moula $F_{1}$ hybrid) on Comparison of population dynamics of important insect pests and their relationship with weather parameters in open field and cover cultivation. The results revealed that whitefly, aphid and leaf miner were most important insects damaging tomato during November to March in this region under open conditions whereas leaf miner and whitefly in poly house. The peak population of these pests was observed during 8 and 9 SMW under both conditions. Pest population and density fluctuation is very low in poly house when compared to open condition expect the leaf miner whose population was high in poly house. Weather relations revealed that Pests under open condition showed greater association with weather variables than in poly house. Whereas canopy temperature, light intensity showed greater degree of association with pests in compression with air temperature and $\mathrm{BSH}$ recorded.

\section{Introduction}

Tomato (Solanum lycopersicum Linn.) is an essential vegetable of our daily diet. A popular and versatile food ranking third in the world's vegetable production, next to potato and sweet potato and placing itself in first place among the processing crops. A wide range of insects attack tomato and forms major limiting factor in its successful cultivation and in improvement of yield. Among the various insects pest attacking tomato such as aphids (Aphis gossypii), thrips (Thrips tabaci) and whiteflies (Bemisia tabaci) act as a vector of many virus diseases.
Some lepidopteron insects such as tobacco caterpillar, Spodoptera litura and tomato fruit borer, Helicoverpa armigera can cause reduction in growth or death of tomato plant by feeding on leaves and fruits. Now a day's leaf miner problem is increasing day by day in poly house conditions. Crop production as well as infestation of crops with various pests and diseases is mainly influenced by the weather factors. This results a considerable loss in the yield and quality of production. In order to protect crop from pest and adverse climatic conditions and growing irrespective 
of their season protected structures are erected. Greenhouse (polyhouse) is a framed or inflated structure covered with a transparent or translucent materials, in which crop could be grown under the conditions of partially controlled environment and which is large enough to permit a person to carry out cultural operations. Polyhouses protect the growing crops against the insect - pest and diseases (biotic stress) and thus improve the fruit quality and increase the production and productivity per unit area/unit time. Tomato is the most important, high value, commercial vegetable crop for which demand in the country is increasing day by day with increasing population. However, very limited information (Singh et al., 2001 and Pant et al., 2001) is available on cultivation of this crop under polyhouse condition. Therefore, an attempt has been made in the present study on insect pest attacking tomato under open and cover cultivation and their weather relations.

\section{Materials and Methods}

Experiment was conducted at Central Research Farm, Gayeshpur, Bidhan Chandra Krishi Viswavidyalaya, Nadia, West Bengal. During December 2016 to March 2017 on tomato (Moula). Raised nursery seedbeds of 1 $\mathrm{m}$ wide were constructed on 25.10.2016. The seeds were sown and covered lightly with soil and watered, then one of the nursery beds was covered with insect proof net and other was left as such. After 30 days seedlings were ready to transplant. Seedlings grown under mosquito net were transplanted in poly house and the other was transplanted in open field. The seedlings of 30 days old, vigorous and uniform size were selected and transplanted with a spacing of $75 \times 70 \mathrm{~cm}$ on 26.11 .2016 under both conditions. And there were four replications Watering was done immediately after transplanting. Irrigation by drip and fertilizer dose of NPK is 100:80:80 $\mathrm{kg} / \mathrm{ha} .1 / 3^{\text {rd }}$ of Nitrogen total $\mathrm{P}_{2} \mathrm{O}_{5}$ and $\mathrm{K}_{2} \mathrm{O}$ are applied as basal and remaining dose of nitrogen is applied as $1 / 3^{\text {rd }}$ at 25DAT and 45DAT. No management practices against pest and diseases were followed. Randomly five plants in each replication were selected for counting insects. Population of sucking pests recorded on five random leaves. Where as for tobacco caterpillar (Spodoptera liura) and fruit borer (Helicoverpa armigera) whole plant was observed both in open condition and poly house. In open and poly house maximum and minimum temperature $\left({ }^{0} \mathrm{C}\right)$ were measured using maximum and minimum thermometer, maximum and minimum relative humidity (\%) using dry and wet bulb thermometer, canopy temperature and light intensity were measured using infrared thermometer and lux meter.

\section{Result and Discussion}

Aphids made its first appearance 4 DAT on crop both under open and poly house conditions with a population load of 2.10 aphid/leaf in open and 1.15 aphid /leaf under poly house. And remained present on the crop for 15 weeks in open conditions and 14 weeks in poly house. Peak population under both conditions were observed on 84 DAT that is 8 SMW (12.00 aphids/leaf) in open and (2.5 aphids/leaf) in poly house. After that population had decreased. Maximum and average relative humidity exhibited significant negative correlation with aphid population under both conditions and minimum relative humidity showed significant negative correlation under open condition. these findings are more or less conformity with findings of Chakraborty (2011 b) who reported that population of aphid initiated at about48 standard meteorological weeks (SMW) initially population grow upto $52 \mathrm{SMW}$ then steadily upto 6 SMW attaining the maximum at about 8 SMW which was maintained up to about 11 SMW and also reported that minimum 
temperature, temperature gradient, average temperature minimum relative humidity has negative correlation with aphid population.

White fly population first appeared at 4 DAT both in open and poly house with a population load of 0.15 white fly/leaf in open and 0.05 white fly /leaf under poly house and remained present on the crop for 14 weeks in open and poly house. Peak population under both conditions was observed on 84 DAT that is 8 SMW (4.6 white fly/leaf) in open and (2.5 whitefly/leaf) in poly house. Maximum, average temperature, Maximum, Minimum, average relative humidity, average canopy temperature and light intensity exhibited significant positive correlation with white flypopulation in open condition where as in poly house condition Minimum and average relative humidity exhibited significant negative correlation. These findings are more or less conformity with findings of Chaudhuri et al., (2001) reported the whitefly population reached the highest level (1.68/ plant) during middle of February and high level was maintained from mid-February to mid-March. Selvaraj and Ramesh (2012) reported that
Whitefly population was build up showed a significant and positive correlation with maximum and minimum temperature whereas, it was significant and negative association with evening relative humidity.

Thrips population first appeared at 14 DAT (49 SMW) in open and 70 DAT (6 SMW) in poly house with a population load of 0.10 thrips/leaf in open and 0.05 thrips /leaf under poly house and remained present on the crop for 9 weeks in open and 2 weeks in poly house.

Peak population under open condition was observed 77 DAT that is 7 SWM (1.20 thrips/leaf) (Table 1). Highest pest attack has been found to take place from 4 SMW to 7 SMW under open conditions and pest population was negligible under poly house. Maximum, Minimum and average relative humidity was significant negatively correlated with thrips population under open condition and all weather parameters were statistically non-significant under poly house condition (Table 2).

Table.1 Weekly meteorological data and incidence of insect pests of tomato under open field condition

\begin{tabular}{|c|c|c|c|c|c|c|c|c|c|c|c|c|c|c|c|}
\hline SMW & aphids & whitefly & thrips & $\begin{array}{l}\text { leaf } \\
\text { miner }\end{array}$ & $\begin{array}{l}\text { Fruit } \\
\text { borer }\end{array}$ & $\begin{array}{l}\text { Tobacco } \\
\text { catterpillar }\end{array}$ & $\begin{array}{c}\mathrm{T} \\
\text { Maximum } \\
\left({ }^{\circ} \mathrm{C}\right)\end{array}$ & $\begin{array}{c}\mathrm{T} \\
\text { Minimum } \\
\left({ }^{\circ} \mathrm{C}\right)\end{array}$ & $\begin{array}{c}\mathrm{T} \\
\text { Average } \\
\left({ }^{\circ} \mathrm{C}\right)\end{array}$ & $\begin{array}{c}\mathrm{RH} \\
\text { Maximum } \\
(\%)\end{array}$ & $\begin{array}{c}\text { RH } \\
\text { Minimum } \\
(\%)\end{array}$ & $\begin{array}{c}\mathrm{RH} \\
\text { Average } \\
(\%)\end{array}$ & $\begin{array}{l}\text { Canopy } \\
\text { Temperature } \\
\left({ }^{\circ} \mathrm{C}\right)\end{array}$ & $\begin{array}{l}\text { Light } \\
\text { intensity } \\
\text { (100lux) }\end{array}$ & BSH \\
\hline 48 & 2.10 & 0.15 & 0.00 & 0.15 & 0.00 & 0.00 & 29.36 & 16.57 & 22.96 & 93.00 & 58.29 & 75.64 & 29.70 & 512.00 & 4.7 \\
\hline 49 & 2.40 & 0.70 & 0.10 & 0.25 & 0.00 & 0.05 & 27.76 & 14.99 & 21.37 & 93.71 & 57.00 & 75.36 & 28.00 & 497.00 & 7.7 \\
\hline 50 & 2.50 & 1.50 & 0.10 & 0.00 & 0.00 & 0.00 & 25.30 & 10.80 & 18.05 & 94.14 & 54.57 & 74.36 & 26.20 & 469.00 & 7.3 \\
\hline 51 & 1.85 & 0.49 & 0.20 & 0.00 & 0.00 & 0.00 & 25.93 & 12.43 & 19.18 & 92.00 & 57.86 & 74.93 & 27.00 & 480.00 & 3.9 \\
\hline 52 & 1.40 & 1.00 & 0.35 & 0.05 & 0.00 & 0.00 & 25.49 & 13.43 & 19.46 & 95.75 & 66.13 & 80.94 & 26.50 & 476.00 & 2.7 \\
\hline 1 & 2.60 & 0.30 & 0.50 & 0.00 & 0.00 & 0.00 & 25.67 & 12.41 & 19.05 & 94.86 & 57.14 & 76.00 & 27.75 & 486.00 & 5.5 \\
\hline 2 & 9.00 & 0.30 & 0.60 & 0.00 & 0.00 & 0.00 & 24.13 & 10.59 & 17.35 & 91.00 & 47.29 & 69.14 & 26.30 & 476.00 & 5.9 \\
\hline 3 & 8.20 & 0.50 & 0.75 & 0.10 & 0.10 & 0.60 & 26.29 & 8.80 & 17.55 & 90.00 & 43.29 & 66.64 & 28.50 & 420.00 & 7.7 \\
\hline 4 & 7.50 & 2.20 & 0.95 & 0.10 & 0.15 & 0.65 & 27.66 & 11.81 & 19.75 & 90.00 & 50.43 & 70.21 & 29.45 & 560.00 & 6.6 \\
\hline 5 & 7.75 & 2.10 & 0.90 & 0.20 & 0.30 & 0.50 & 26.88 & 12.61 & 19.75 & 91.00 & 53.20 & 72.10 & 27.40 & 552.00 & 7.0 \\
\hline 6 & 6.65 & 2.90 & 1.10 & 0.60 & 0.60 & 0.40 & 27.40 & 13.47 & 20.44 & 90.30 & 41.00 & 65.65 & 29.87 & 555.00 & 8.8 \\
\hline 7 & 10.50 & 3.50 & 1.20 & 1.50 & 0.70 & 0.60 & 29.05 & 14.70 & 21.88 & 89.83 & 43.83 & 66.83 & 30.20 & 650.00 & 5.6 \\
\hline 8 & 12.00 & 4.60 & 1.05 & 1.70 & 0.85 & 0.85 & 30.25 & 16.00 & 23.13 & 88.57 & 44.28 & 66.43 & 33.37 & 675.00 & 5.9 \\
\hline 9 & 7.50 & 2.85 & 0.90 & 2.65 & 1.20 & 1.15 & 31.08 & 17.18 & 24.13 & 91.28 & 47.00 & 69.14 & 33.43 & 760.00 & 8.8 \\
\hline 10 & 2.10 & 0.00 & 0.75 & 0.50 & 0.00 & 0.00 & 32.00 & 23.00 & 27.50 & 89.00 & 46.00 & 67.50 & 31.84 & 860.00 & 4.6 \\
\hline
\end{tabular}


Table.2 Weekly meteorological data and incidence of insect pests of tomato in poly house condition

\begin{tabular}{|c|c|c|c|c|c|c|c|c|c|c|c|c|c|c|}
\hline $\begin{array}{c}\text { SM } \\
\text { W }\end{array}$ & aphids & whitefly & thrips & $\begin{array}{l}\text { leaf } \\
\text { miner }\end{array}$ & $\begin{array}{l}\text { Fruit } \\
\text { borer }\end{array}$ & $\begin{array}{l}\text { Tobacco } \\
\text { catterpillar }\end{array}$ & $\begin{array}{c}\mathrm{T} \\
\text { Maximum } \\
\left({ }^{\circ} \mathrm{C}\right)\end{array}$ & $\begin{array}{c}\mathrm{T} \\
\text { Minimu } \\
\mathrm{m} \\
\left({ }^{\circ} \mathrm{C}\right) \\
\end{array}$ & $\begin{array}{c}\mathrm{T} \\
\text { Average } \\
\left({ }^{\circ} \mathrm{C}\right)\end{array}$ & $\begin{array}{c}\mathrm{RH} \\
\text { Maximum } \\
(\%)\end{array}$ & $\begin{array}{c}\mathrm{RH} \\
\text { minimum } \\
(\%)\end{array}$ & $\begin{array}{c}\text { RH } \\
\text { Average } \\
(\%)\end{array}$ & $\begin{array}{l}\text { Canopy } \\
\text { Temperature } \\
\left({ }^{\circ} \mathrm{C}\right)\end{array}$ & $\begin{array}{l}\text { Light } \\
\text { intensity } \\
\text { (100lux) }\end{array}$ \\
\hline 48 & 1.15 & 0.05 & 0.00 & 0.10 & 0.00 & 0.00 & 29.36 & 16.57 & 22.96 & 93.00 & 58.29 & 75.64 & 29.70 & 512.00 \\
\hline 49 & 0.65 & 0.20 & 0.00 & 0.15 & 0.00 & 0.05 & 27.76 & 14.99 & 21.37 & 93.71 & 57.00 & 75.36 & 28.00 & 497.00 \\
\hline 50 & 0.35 & 0.35 & 0.00 & 0.00 & 0.00 & 0.00 & 25.30 & 10.80 & 18.05 & 94.14 & 54.57 & 74.36 & 26.20 & 469.00 \\
\hline 51 & 0.20 & 0.52 & 0.00 & 0.00 & 0.00 & 0.05 & 25.93 & 12.43 & 19.18 & 92.00 & 57.86 & 74.93 & 27.00 & 480.00 \\
\hline 52 & 0.40 & 0.60 & 0.00 & 0.15 & 0.00 & 0.00 & 25.49 & 13.43 & 19.46 & 95.75 & 66.13 & 80.94 & 26.50 & 476.00 \\
\hline 1 & 0.00 & 1.05 & 0.00 & 0.00 & 0.00 & 0.25 & 25.67 & 12.41 & 19.05 & 94.86 & 57.14 & 76.00 & 27.75 & 486.00 \\
\hline 2 & 1.15 & 1.23 & 0.00 & 0.15 & 0.00 & 0.00 & 24.13 & 10.59 & 17.35 & 91.00 & 47.29 & 69.14 & 26.30 & 476.00 \\
\hline 3 & 1.15 & 1.20 & 0.00 & 0.75 & 0.05 & 0.00 & 26.29 & 8.80 & 17.55 & 90.00 & 43.29 & 66.64 & 28.50 & 420.00 \\
\hline 4 & 0.60 & 0.80 & 0.00 & 1.24 & 0.00 & 0.00 & 27.66 & 11.81 & 19.75 & 90.00 & 50.43 & 70.21 & 29.45 & 560.00 \\
\hline 5 & 0.75 & 0.75 & 0.00 & 1.99 & 0.00 & 0.00 & 26.88 & 12.61 & 19.75 & 91.00 & 53.20 & 72.10 & 27.40 & 552.00 \\
\hline 6 & 0.55 & 1.10 & 0.05 & 2.40 & 0.10 & 0.15 & 27.40 & 13.47 & 20.44 & 90.30 & 41.00 & 65.65 & 29.87 & 555.00 \\
\hline 7 & 1.25 & 1.92 & 0.00 & 4.94 & 0.12 & 0.37 & 29.05 & 14.70 & 21.88 & 89.83 & 43.83 & 66.83 & 30.20 & 650.00 \\
\hline 8 & 2.50 & 2.10 & 0.05 & 8.85 & 0.15 & 0.40 & 30.25 & 16.00 & 23.13 & 88.57 & 44.28 & 66.43 & 33.37 & 675.00 \\
\hline 9 & 0.35 & 1.10 & 0.00 & 18.05 & 0.25 & 0.55 & 31.08 & 17.18 & 24.13 & 91.28 & 47.00 & 69.14 & 33.43 & 760.00 \\
\hline 10 & 0.00 & 0.00 & 0.00 & 17.23 & 0.00 & 0.00 & 32.00 & 23.00 & 27.50 & 89.00 & 46.00 & 67.50 & 31.84 & 860.00 \\
\hline
\end{tabular}

Table.3 Correlation coefficient (r) of pests of tomato with weather parameters under open and poly house condition

\begin{tabular}{|c|c|c|c|c|c|c|c|c|c|c|c|c|c|}
\hline \multicolumn{2}{|c|}{ Environmental parameter } & OPEN & $\begin{array}{c}\text { POLY } \\
\text { HOUSE }\end{array}$ & OPEN & $\begin{array}{c}\text { POLY } \\
\text { HOUSE }\end{array}$ & OPEN & $\begin{array}{c}\text { POLY } \\
\text { HOUSE }\end{array}$ & OPEN & $\begin{array}{c}\text { POLY } \\
\text { HOUSE }\end{array}$ & OPEN & $\begin{array}{c}\text { POLY } \\
\text { HOUSE }\end{array}$ & OPEN & $\begin{array}{c}\text { POLY } \\
\text { HOUSE }\end{array}$ \\
\hline \multicolumn{2}{|c|}{ Insect pest } & \multicolumn{2}{|l|}{$\begin{array}{l}\text { Leaf } \\
\text { miner }\end{array}$} & \multicolumn{2}{|l|}{$\begin{array}{l}\text { Fruit } \\
\text { borer }\end{array}$} & \multicolumn{2}{|l|}{$\begin{array}{c}\text { Tbacco } \\
\text { caterpi } \\
\text { llar }\end{array}$} & \multicolumn{2}{|l|}{ Aphids } & \multicolumn{2}{|l|}{ Whitefly } & \multicolumn{2}{|l|}{ Thrips } \\
\hline \multirow{3}{*}{$\begin{array}{c}\text { Temperature } \\
{ }^{0} \mathrm{C}\end{array}$} & Maximum & $0.819^{* *}$ & $0.764^{* *}$ & $0.776^{* *}$ & $\mathbf{0 . 7 8 3}^{* *}$ & $0.719^{* *}$ & $0.819^{* *}$ & $0.764^{* *}$ & $0.776^{* *}$ & $\mathbf{0 . 7 8 3}^{* *}$ & $0.719^{* *}$ & $0.741^{* *}$ & $0.741^{* *}$ \\
\hline & Minimum & $0.673^{* * *}$ & $0.625^{*}$ & $0.582^{*}$ & $0.603^{*}$ & 0.318 & $0.673^{* * *}$ & $0.625^{*}$ & $0.582^{*}$ & $0.603^{*}$ & 0.318 & $0.652^{*}$ & $0.652^{*}$ \\
\hline & Average & $0.774^{* *}$ & $0.725^{* *}$ & $0.702^{* *}$ & $0.722^{* *}$ & 0.525 & $0.774^{* *}$ & $0.725^{* *}$ & $0.702^{* *}$ & $\mathbf{0 . 7 2 2}^{* *}$ & 0.525 & $0.730^{* *}$ & $\mathbf{0 . 7 3 0}^{* *}$ \\
\hline \multirow{3}{*}{$\begin{array}{c}\text { Relative } \\
\text { Humidity } \\
(\%)\end{array}$} & Maximum & -0.455 & -0.087 & $-0.577^{*}$ & -0.164 & $0.716^{* *}$ & -0.455 & -0.087 & $-0.577^{*}$ & -0.164 & $-0.716^{* *}$ & 0.009 & 0.009 \\
\hline & Minimum & -0.502 & -0.432 & $-0.626^{*}$ & $-0.606^{*}$ & $0.667^{* *}$ & -0.502 & -0.432 & $-0.626^{*}$ & $-0.606^{*}$ & $-0.667^{* *}$ & -0.441 & -0.441 \\
\hline & Average & -0.504 & -0.367 & $-0.630^{*}$ & -0.525 & $0.695^{*}$ & -0.504 & -0.367 & $-0.630^{*}$ & -0.525 & $-0.695^{* *}$ & $\begin{array}{l}-0.348 \\
\end{array}$ & -0.348 \\
\hline BSH (hours) & Average & 0.348 & - & 0.446 & - & 0.512 & 0.348 & - & 0.446 & - & 0.512 & - & - \\
\hline $\begin{array}{c}\text { Canopy } \\
\text { temperature } \\
\left({ }^{\circ} \mathrm{C}\right) \\
\end{array}$ & Average & $0.875^{* *}$ & $0.726^{* *}$ & $0.871^{* *}$ & $0.587^{*}$ & $0.828^{* *}$ & $0.875^{* *}$ & $0.726^{* *}$ & $0.871^{* * *}$ & $0.587^{*}$ & $0.828^{* *}$ & $0.628^{*}$ & $0.628^{*}$ \\
\hline $\begin{array}{c}\text { Light } \\
\text { intensity } \\
\text { (lux) } \\
\end{array}$ & Average & $0.942^{* *}$ & $0.730 *$ & $0.937^{* *}$ & $0.735^{* *}$ & $0.801^{* *}$ & $0.942^{* * *}$ & $\mathbf{0 . 7 3 0}^{* *}$ & $0.937^{* *}$ & $0.735^{* *}$ & $0.801^{* *}$ & $0.790^{* *}$ & $0.790^{* *}$ \\
\hline
\end{tabular}

*Significant at $5 \%$ level of significance **Significant at $1 \%$ level of significance
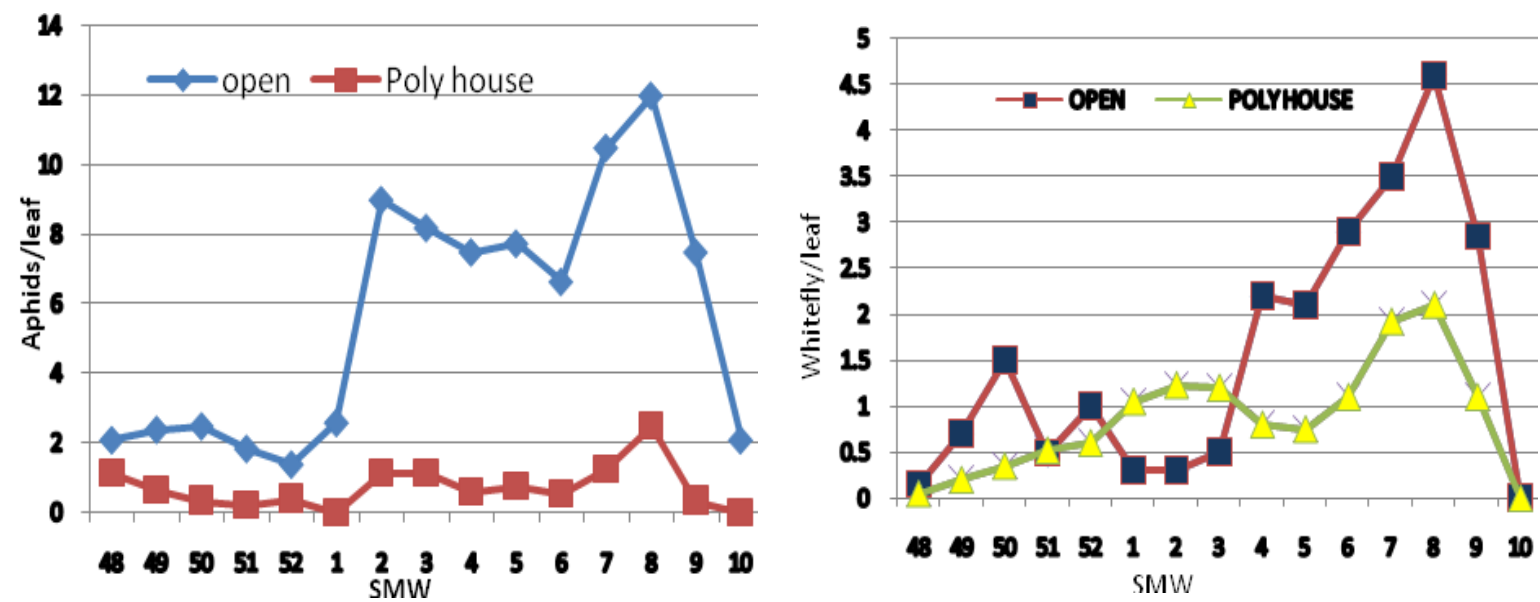

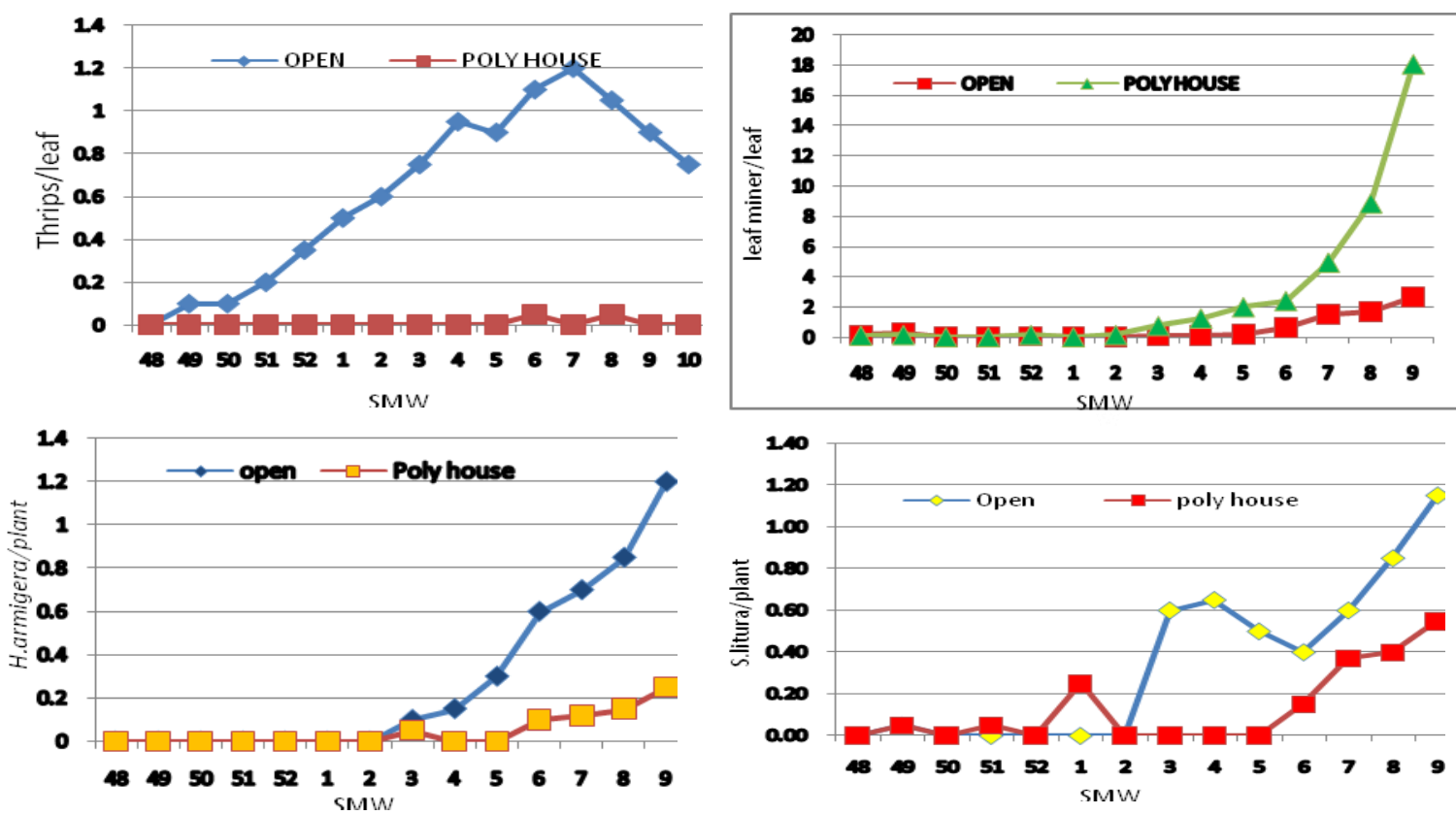

Fig.1 a) Aphids b) Whitefly c) Leaf miner d) Leaf curl virus symptom f) Fruit borer (Helicoverpa armigera) Larva and its infestation on tomato fruit e) Tobacco caterpillar (Spodoptera litura)
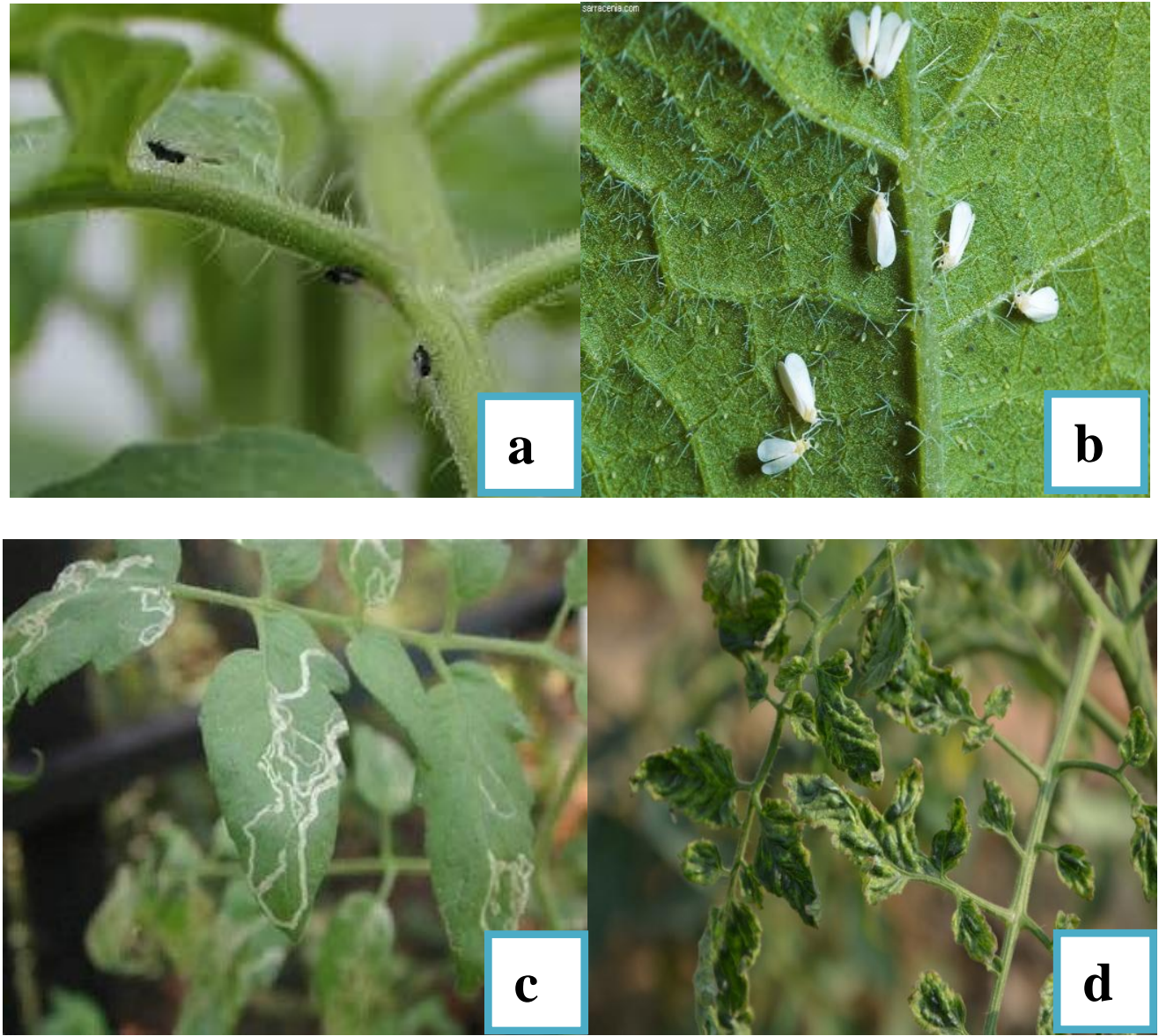


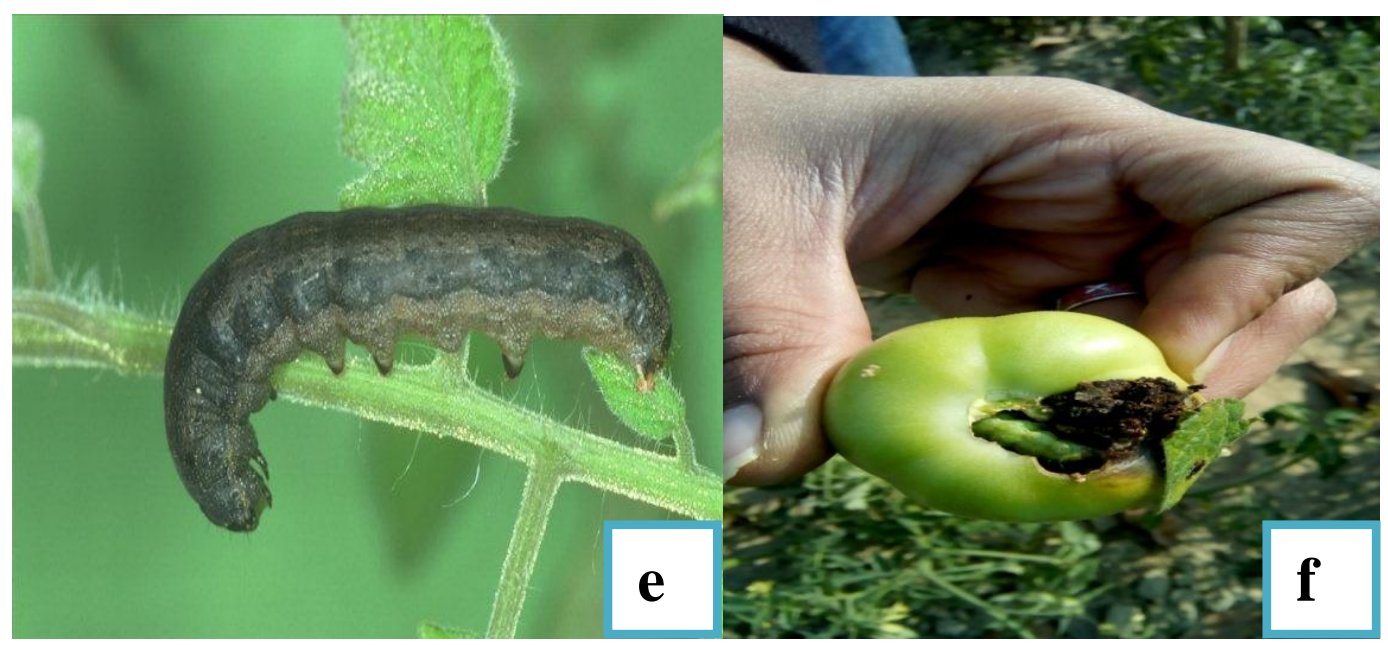

Fig.2 a) Nursery raised in open b) Nursery raised under net c) Thermometer in open d) Thermometer in poly house
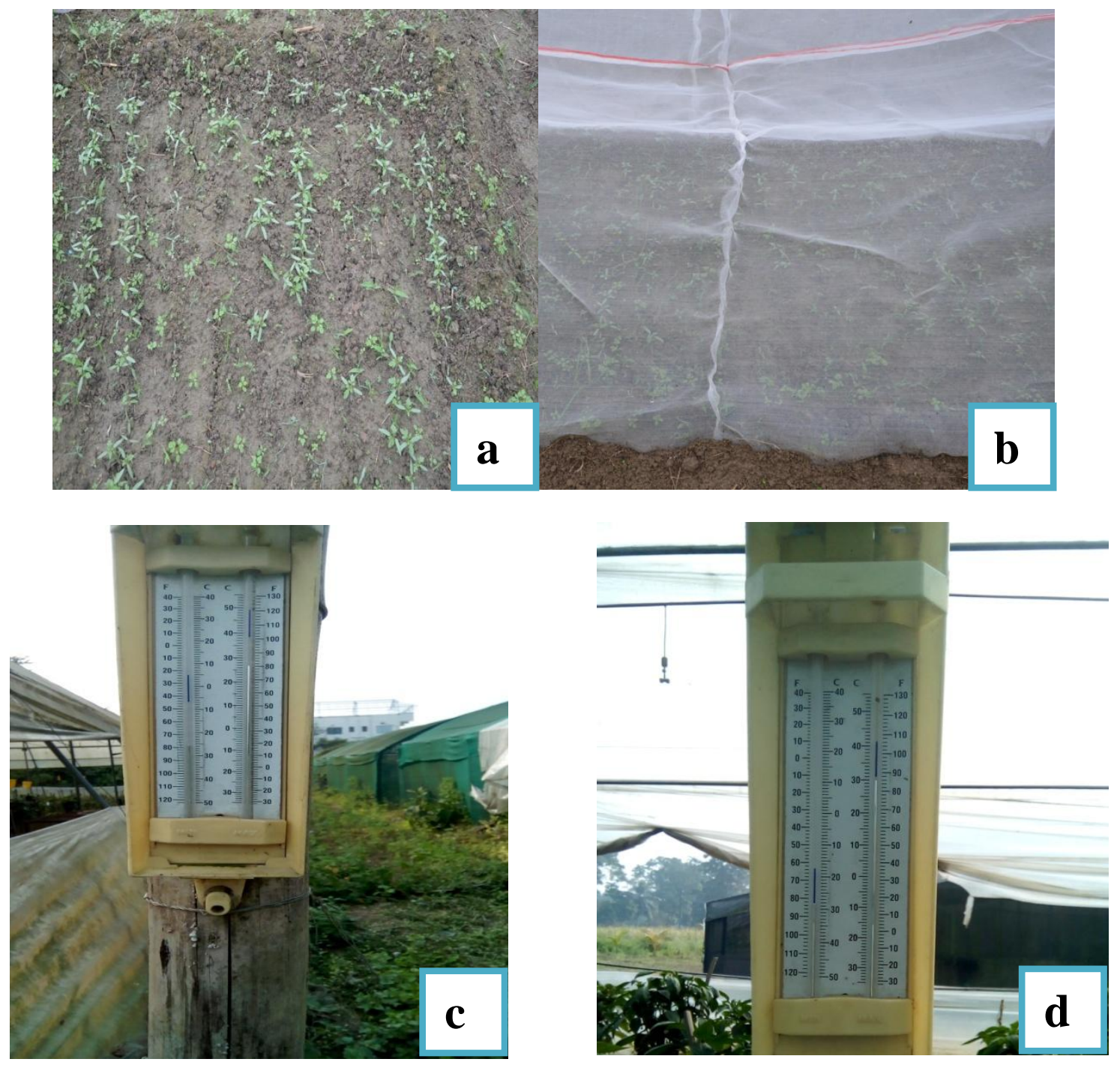
Leaf miner first appeared at 4 DAT both in open and poly house condition. With a population load of 0.15 leaf miner/plant in open and 0.10 leaf miner/plant under poly house and remained present on the crop for 10 weeks in open and 11 weeks in poly house. Peak population under both conditions was observed on 98 DAT (9SMW) (2.65 leaf miner/plant) in open and (18.05leaf miner/plant) under poly house. Highest pest attack has been found to take place from $7 \mathrm{SMW}$ to $9 \mathrm{SMW}$ under both conditions. Population of leaf miner was high in poly house in comparison to open field. Maximum, minimum, average temperature, average canopy temperature and light intensity exhibited significant positive correlation with leaf miner population in open and poly house conditions. These findings are more or less conformity with findings of Rishikesh Mandloi et al., (2015) reported L. trifolii Increasing trend was observed in this case with crop growth stages. The activity was observed43rd to 12th SW (22 Oct 2012 to 25 March 2013) with three distinct peaks during 10th, 11th and 12th SW $(44.56 \%, 45.95$ and $44.02 \%)$ and maximum leaf infestation was recordedon11th SW $(45.95 \%)$.

Murphy (2014) reported that leaf miners can complete their life cycle within 14 days at temperatures up to $30^{\circ} \mathrm{C}$, and up to 24 days at $20^{\circ} \mathrm{C}$. In the present study temperature in poly house is $20-26{ }^{\circ} \mathrm{C}$ and $2{ }^{\circ} \mathrm{C}$ higher than the open temperature which is favourable for leaf miner. Chaudhuri and Senapati (2004) reported that Temperature, and rainfall showed significantly positive correlation with leaf miner incidence while non-significantly positive correlation with average R.H. Temperature and R.H. gradient showed significantly negative correlation.

Helicoverpa made its first appearance on the crop on third week of January (3 SMW) in open and poly house conditions. With a population load of 0.10 larva/plant in open and 0.05 larva/plant under poly house. Peak population under open and poly house condition was observed 98 DAT that is 9 SWM (1.20 larva/plant $)$ in open and (0.25 larva/plant) in poly house condition. Pest remained present on the crop for 7 weeks in open and 4 weeks in poly house condition.

Maximum, minimum, average temperature, average canopy temperature and light intensity exhibited significant positive correlation with Helicoverpa population in open and poly house conditions whereas Minimum relative humidity was significant and negatively correlated under both conditions.

Maximum and average relative humidity was significant and negatively correlated only under open condition. These findings are more or less conformity with findings of Singh et al., (2011b) significant and positive correlation with maximum and minimum temperature whereas, it was significant and negative association with evening relative humidity (Table 3; Figs. 1, 2).

Spodoptera first appeared at 7 DAT in open and poly house conditions. With a population load of 0.05 larva/plant in open and 0.05 larva/plant under polyhouse. And remained present on the crop constantly for 7 weeks in open and 4 weeks in poly house. Peak population under both conditions was observed 98 DAT that is 9 SWM (1.15 larvae/plant) in open and (0.55larvae/plant) in poly house condition.

Highest pest attack has been found to take place from 7 SMW to 9 SMW under open and poly house after that population had decreased. Maximum temperature, average canopy temperature and light intensity exhibited significant positive correlation with spodoptera population in open and poly house conditions whereas minimum and average temperature showed significant positive correlation in poly house and maximum, minimum, average relative humidity showed significant negative correlation under open condition. These findings are more or less conformity with findings of Prashant et al., (2007) who reported that the population of Spodoptera litura was positively correlated with the mean temperature but negatively correlated with relative humidity. 
Population of insect pest was found minimum under polyhouse condition and maximum in open field. Because of the controlled environment in poly house and due to presence of physical barrier, pests under open condition showed greater association with weather variables than in poly house condition because the poly house have controlled environment and absolute number of pest population is very much lower than open condition.

\section{Acknowledgement}

First and foremost I would like to thank the Almighty god for giving me this opportunity. I feel unfathomable euphoria to pronounce my Heartful veneration and gratitude to Prof. S. Jha, Department of agricultural Entomology, BCKV. I further extend my sincere gratitude to Dr. S. Dutta, Department of Plant Pathology and Dr. A. Saha Department of Agricultural Meteorology and Physics for providing their sincere guidance, keen interest, inestimable inspiration and valuable suggestions throughout the course of investigation. I further extend my sincere thanks to Mrs. Malabika Chakraborty SMS of plant protection at KVK Nadia for helping me in analysis and research work in collection and compilation of data. Last but not least I want to thank all my friends who helped and encouraged me in conducting my research work from starting to end of work.

\section{References}

Chakraborty, K., 2011b. Incidence of aphids, Aphis gossypii Glover (Hemiptera: Aphidae) on tomato crop in the agro climatic condition of Northen parts of West Bengal, India. World Journal of
Zoology, 6(2): 187-191.

Chaudhuri, N., and Senapati, S. K. 2004. Incidence and biology of leaf miner, Liriomyza trifolii (Burg.) on tomato as influenced by weather conditions. Annals of Protection Sciences, 12: 55-58.

Chaudhuri, N., Deb, D. C. and Senapati, S. K. 2001. Biology and fluctuation of white fly (Bemisla tabaci Genn.) population on tomato as influenced by abiotic factors under Terai region of West Bengal. Indian Journal of Agricultural Research, 35(3): 155-160.

Pant, J., Joshi, R.P., Bhoj, A.S. and Kumar, N.2001.Identification of suitable vegetable cropping sequence for greenhouse cultivation in Uttaranchal hills. Veg. Sci., 2:143-145.

Prashant, K., Prasad, C. S. and Tiwari, G. N. 2007. Population intensity of insect pests of cabbage in relation to weather parameters. Annals of Plant Protection Sciences, 15(1): 245-246.

Selvaraj, S., and Ramesh, V., 2012. Seasonal abundance of whitefly, Bemisia tabaci Gaennadius and their relation to weather parameters in cotton. International Journal of Food, Agriculture and Veterinary Sciences, 2(3): 57-63.

Singh, A.K., Singh, A.K., Chandra, P. and Gupta, M.J. 2001. Effect of urea doses on growth and fruits yield of strawberry cultivation under greenhouse condition. J. progressive hort., 33(2):194-198.

Singh, K., Raju, S. V. S. and Singh, D. K. 2011b. Population Succession of tomato fruit borer (Helicoverpa armigera) on tomato (Lycopersicon esculentum Mill.) agro-ecosystem in eastern region of U. P. Vegetable Science, 38(2): 152-155.

\section{How to cite this article:}

Nagamandla Ramya Sri, Shantanu Jha and Nagulapally Sneha Latha. 2017. Insect Pests of Tomato and Their Weather Relations under Open and Cover Cultivation. Int.J.Curr.Microbiol.App.Sci. 6(9): 368-375. doi: https://doi.org/10.20546/ijcmas.2017.609.046 